\title{
PENGEMBANGAN BAHAN AJAR TEMATIK BERBASIS ISLAM DAN KEARIFAN LOKAL KELAS IV MIN SEDURI \& MIS NURUL AMAL MOJOKERTO
}

\author{
Benny Angga Permadi \\ Institut Pesantren KH. Abdul Chalim Mojokerto \\ Email: bennyangga68@gmail.com \\ Ika Agustin Adityawati \\ Institut Pesantren KH. Abdul Chalim Mojokerto \\ Email :agustinadityawati@gmail.com
}

\begin{abstract}
The Development of Thematic Teaching Materials Islam and Local Wisdom Based Class IV of MIN (Madrasah Ibtidaiyah Negeri (State of Islamic Elementary School)) Seduri and MIS (Private of Islamic Elementary School) Nurul Amal Mojokerto Regenct. The application of curriculum 2013 requires every student of elementary school from first up to sixth graders to apply thematic study. The interview with the teacher of fourth grader of MIN (Madrasah Ibtidaiyah Negeri (State of Islamic Elementary School)) Seduri and MIS (Private of Islamic Elementary School) Nurul Amal Mojokerto Regency and also the observation in the field show that the teaching materials used from Ministry of Education and Culture of the theme of 'My Place' is not fit in with the condition of students' place in Mojokerto Regency while the essence of curriculum 2013 of thematic study is to support the contextual aspect and close with students' place. Else, the character education in curriculum 2013 must also be applied through Islamic habits which are done in school. These habits are not discussed in guide book from Ministry of Education and Culture. Therefore, this research objective is to develop the product of thematic teaching materials Islamic and local wisdom based. The feasibility of teaching materials

Nazhruna: Jurnal Pendidikan Islam
\end{abstract}

Vol. 1 No 1 Maret 2018. Issn: 2614-8013. Hal. 122-138 
which are developed is assessed according to the validity, interesting, effectiveness and application levels. The research result and development of thematic study materials are in form of (1) thematic teaching materials Islamic and local wisdom based. The materials are integrated with Islamic values in the teaching and learning activities and the materials about local wisdom of Mojokerto Regency such as historical buildings, special foods, dances and handicrafts. (2) the experts validity shows percentage of $89.17 \%$ with the criteria of high validity and deserved to be used. (3) the interesting level shows percentage of $93.12 \%$ with the criteria of high interesting and deserved to be used. (4) the effectiveness level shows percentage of 78.01 with the criteria of high effective. (5) application level shows percentage of $86.08 \%$ with the criteria of very good and fulfil the elements of application for teaching materials.

Keywords: development of teaching materials, Islamic based, local wisdom

\section{Abstrak}

Pengembangan Bahan Ajar Tematik Islam dan Kearifan Lokal Berbasis Kelas IV MIN (Madrasah Ibtidaiyah Negeri) Seduri dan SIM (Swasta Sekolah Dasar Islam) Nurul Amal Mojokerto. Penerapan kurikulum 2013 mewajibkan setiap siswa sekolah dasar dari siswa pertama hingga kelas enam untuk menerapkan studi tematik. Wawancara dengan guru siswa kelas IV MIN (Madrasah Ibtidaiyah Negeri)) Seduri dan SIM (Sekolah Dasar Islam Swasta) Kabupaten Nurul Amal Mojokerto dan juga pengamatan di lapangan menunjukkan bahwa bahan ajar yang digunakan dari Kementerian Pendidikan dan Kebudayaan dengan tema 'My Place' tidak sesuai dengan kondisi tempat siswa di Kabupaten Mojokerto sementara esensi kurikulum 2013 studi tematik adalah untuk mendukung aspek kontekstual dan dekat dengan tempat siswa. Lain, pendidikan karakter dalam kurikulum 2013 juga harus diterapkan melalui kebiasaan-kebiasaan Islam yang dilakukan di sekolah. Kebiasaan ini tidak dibahas dalam buku panduan dari Kementerian Pendidikan dan Kebudayaan. Oleh karena itu, tujuan penelitian ini adalah 
untuk mengembangkan produk bahan ajar tematik berbasis kearifan lokal dan Islam. Kelayakan bahan ajar yang dikembangkan dinilai sesuai dengan tingkat validitas, menarik, efektivitas dan aplikasi. Hasil penelitian dan pengembangan bahan ajar tematik adalah berupa (1) bahan ajar tematik berbasis kearifan lokal dan kearifan lokal. Materi diintegrasikan dengan nilai-nilai Islam dalam kegiatan belajar mengajar dan materi tentang kearifan lokal Kabupaten Mojokerto seperti bangunan bersejarah, makanan khusus, tarian dan kerajinan tangan. (2) validitas ahli menunjukkan persentase sebesar 89,17\% dengan kriteria validitas tinggi dan layak untuk digunakan. (3) tingkat menarik menunjukkan persentase $93,12 \%$ dengan kriteria tinggi menarik dan layak untuk digunakan. (4) tingkat efektivitas menunjukkan persentase 78,01 dengan kriteria efektif tinggi. (5) tingkat aplikasi menunjukkan persentase sebesar 86,08\% dengan kriteria sangat baik dan memenuhi unsur aplikasi untuk bahan ajar.

Kata Kunci: Pengembangan Bahan Ajar, Kerifan Lokal, Islam

\section{Pendahuluan}

Tantangan kehidupan global sudah terasa dampaknya bagi kehidupan masyarakat Indonesia. Arus Globalisasi telah melahirkan ekses negatif terhadap melemahnya kearifan budaya lokal dan budi pekerti manusia ${ }^{1}$. Dari aspek budaya, Seperti yang sudah terjadi pada beberapa kebudayaan yang diklaim dan diatas namakan milik negara Malaysia yakni batik, Reog, lagu Rasa Sayange, Tari Pendet. Bukan tidak mungkin suatu saat akan semakin banyak budaya milik kita dirampas oleh negara tetangga apabila kita tidak menjaga dan melestarikannya. Disamping hal itu dari aspek budi pekerti dan moral diperparah pula dengan keadaan masyarakat muda Indonesia yang berkiblat dan mendambadambakan kebudayaan barat seperti kriteria fashion, kegemaran

\footnotetext{
${ }^{1}$ Muhammad Anas Ma arif, 'Pendidikan Islam Dan Tantangan Modernitas', Nidhomul Haq: Jurnal Manajemen Pendidikan Islam 1, no. 2 (26 March 2016): 48.
} 
selera makan, dunia hiburan, bahasa komunikasi, gaya hidup, interaksi anak dengan orang tua, budaya sekularisme, hedonisme, dsb.

Ditengah pusaran pengaruh hegemoni global tersebut, fenomena yang telah terjadi juga telah membuat lembaga pendidikan terasa kehilangan ruang gerak. Pendidikan seharusnya mempunyai peran penting dalam menentukan perubahan dan perkembangan cara berfikir masyarakat, terutama bagi pembangunan bangsa dan negara.

Kemajuan suatu kebudayaan bergantung pada cara kebudayaan tersebut mengenali, menghargai, dan memanfaatkan sumber daya manusia yang berkaitan erat dengan kualitas pendidikan yang diberikan oleh guru kepada siswa. Pendidikan seharusnya juga bisa membentuk manusia berakhlakul karimah melalui nilai-nilai islam yang diterapkan dalam pembiasaan disekolah. Menurut Benni Setiawan, dengan pendidikan yang berbasis local wisdom (kearifan lokal) akan membuat seseorang merasa optimis akan terciptanya pendidikan yang mampu memberikan makna bagi kehidupan manusia Indonesia itu artinya pendidikan kemudian akan mempu menjadi spirit yang bisa mewarnai dinamika manusia Indonesia kedepan. ${ }^{2}$ Menurut Aisyah Wardahlia dalam penelitiannya, dalam pendidikan nilai akhlak, pendidik dituntut untuk senantiasa menjadi tauladan bagi peserta didik serta menanamkan nilai-nilai akhlak atau nilai-nilai budi pekerti baik dari sisi kognitif, afektif dan psikomotorik. Pendidikan nilai akhlak secara langsung mengajak peserta didik untuk mencari solusi atas permasalahan yang dihadapi dengan bimbingan dari pendidik (problem possing education). ${ }^{3}$

Pembelajaran tematik merupakan pembelajaran terpadu yang menggunakan tema untuk mengaitkan beberapa mata

\footnotetext{
${ }^{2}$ Benny Setiawan, Agenda Pendidikan Nasional ( Yogyakarta : Ar-Ruz Media Group 2008), hlm.30.

3 Aisyah Wardahlia Kurniawati, Pendidikan Nilai Berbasis Islam (Proses Penanaman Budi Pekerti dalam Bingkai Pendidikan Agama Islam), Skripsi (Malang: UIN Malang, 2009), hlm. 20.
} 
pelajaran sehingga dapat memberikan pengalaman bermakna bagi siswa. Pembelajaran tematik diharapkan dapat mengeksplor pengetahuan, ketrampilan, atau sikap baru. Dengan adanya pembelajaran terpadu siswa akan lebih mudah dalam memahami pembelajaran.

Menurut Sutirjo \& Mamik, menyatakan bahwa pembelajaran tematik merupakan suatu usaha untuk mengintegrasikan pengetahuan, ketrampilan, nilai, atau sikap pembelajaran serta

pemikiran yang kreatif dengan menggunakan tema. Selain itu pendekatan tematik dalam proses pembelajaran siswa akan dilatih untuk menumbuhkan ketrampilan sosial melalui kerjasama. ${ }^{4}$ Kekurangan dari pembelajaran tematik di sekolah-sekolah kita salah satunya yaitu kurangnya ketersediaan bahan bacaan atau sumber informasi yang cukup banyak dan berguna yang mampu menunjang dan memperkaya wawasan. Muatan yang diterapkan pada Kurikulum 2013, mengakibatkan siswa terkendala dalam mencari materi yang ada pada buku paket dan materi yang didapat masih kurang. Hal ini lah yang mendasari sulitnya pembelajaran tematik diterapkan

Dalam pembelajaran tematik tentu tidak terlepas dari keberadaan bahan ajar ${ }^{5}$. Bahan ajar yang berupa buku siswa dan buku guru dari kemendikbud belum sesuai antara KI dan KD dalam muatan kurikulum 2013 dengan materi pembelajaran yang ada pada buku tersebut. Materi pembelajaran dari Kemendikbud cenderung menampilkan potensi daerah di Indonesia secara keseluruhan. Sedangkan siswa sendiri belum mengenal potensi lokal yang ada didaerahnya. Proses Pembelajaran yang baik yaitu siswa belajar dari lingkungan yang terdekat, yaitu belajar dari daerahnya, kemudian belajar daerah keseluruhan. Selain itu dalam

\footnotetext{
${ }^{4}$ Sutirjo \& Mamik, Tematik (Pembelajaran Efektif dalam Kurikulum 2014 (Malang: Bayumedia Publishing 2014), hlm. 6.

${ }^{5}$ Akhmad Sirojuddin, 'Pengembangan Bahan Ajar Mind Mapping Berbasis ICT', Nidhomul Haq : Jurnal Manajemen Pendidikan Islam 1, no. 1 (2016): 15, https://doi.org/10.31538/ndh.v1i1.4.
} 
buku terbitan Kemendikbud masih bersifat umum, dan kurang sempurna apabila dikonsumsi oleh siswa madrasah ibtidayah karena didalamnya tidak terdapat muatan agama islam melalui pendekatan-pendekatan pembelajarannya.

Berdasarkan hasil observasi peneliti terhadap buku paket kelas IV dari Kemendikbud pada tema sembilan diketahui beberapa kekurangan yaitu pemetaan Kompetensi Dasar pada buku guru kurang tepat, indikator belum bersifat kontekstual sehingga siswa belum tahu potensi apa yang dimiliki daerahnya, dan materi kurang menunjang pembelajaran, materi yang dibahas dalam buku $70 \%$ tentang daerah-daerah yang jauh dengan lingkungan tempat tinggal siswa (Papua, Bali, Sumatera dan Jakarta). Dalam buku paket tersebut internalisasi karakter islam belum terlihat, karena memang buku tersebut bersifat umum dan dikonsumsi oleh semua siswa dengan berbeda-beda agama. Di Kabupaten Mojokerto, khususnya di MIS Nurul Amal dan MIN Seduri seluruh siswanya beragama islam karena berada di lingkungan madrasah.

Menindaklanjuti hasil wawancara dan observasi peneliti tersebut, peneliti berupaya mengembangkan bahan ajar yang sudah ada dari Kemendikbud untuk diperbaiki sesuai dengan kearifan lokal Kabupaten Mojokerto. Dalam penelitian ini bahan ajar yang dikembangkan dalam bentuk teknologi cetak (print technologies). Penggunaan bahan ajar cetak dalam pembelajaran memiliki keunggulan dan fungsi yang sangat penting. Menurut Buckingham (dalam Taringan) keunggulan yang diperoleh dari pemanfaatan bahan ajar cetak yaitu ${ }^{6}$ (1) memiliki kesempatan mempelajari sesuai dengan kecepatan masing-masing, (2) kesempatan mengulang atau meninjau kembali (3) kemungkinan mengadakan pemeriksaan atau pengecekkan terhadap ingatan (4) kemudahan membuatcatatan pada pemakaian selanjutnya, (5) kesempatan

\footnotetext{
${ }^{6}$ Henry Guntur Tarigan, Telaah Buku Teks Bahasa Indonesia, (Bandung: Angkasa, 1986), hlm. 16.
} 
khusus yang ditampilkan oleh adanya sarana-sarana visual yang menunjang belajar.

Bahan ajar yang akan peneliti kembangkan adalah bahan ajar dari Kemendikbud Tahun 2013 yaitu Buku Siswa pada tema "Daerah Tempat Tinggalku dengan sub tema "Keunikan Daerah Tempat Tinggalku” (Kemendikbud 2013)

Berdasarkan latar belakang masalah yang telah diuraikan, maka dirumuskan tujuan penelitian dan pengembangan antara lain untuk menghasilkan produk bahan ajar tematik berbasis Islam \& Kearifan Lokal yang dekat dengan lingkungan siswa berada. Produk yang dikembangkan berupa buku belajar siswa, serta untuk menguji kelayakan bahan ajar yang dikembangkan untuk siswa kelas IV MIN Seduri \& MIS Nurul Amal. Kelayakan bahan ajar tematik berupa validasi bahan ajar tematik, tingkat keefektifan bahan ajar tematik, tingkat kemenarikan bahan ajar tematik dan tingkat keterterapan bahan ajar tematik.

\section{Metode}

Model pengembangan bahan ajar tematik yang digunakan dalam penelitian ini adalah Penelitian dan Pengembangan atau Research and Development (R\&D) model Borg \& Gall ${ }^{7}$ pada dasarnya merupakan suatu proses yang digunakan untuk mengembangkan dan memvalidasi produk-produk yang dikembangkan. Berdasarkan pendapat tersebut, maka di dalamnya terdapat proses mengembangkan dan menguji kelayakan dan keefektifan suatu produk dengan kriteria yang disesuaikan dengan produk yang dihasilkan.

Alasan memilih model pengembangan Penelitian dan Pengembangan atau Research and Development (R\&D) model Borg \& Gall adalah : (1) didahului oleh studi lapangan dan studi kajian pustaka terhadap produk yang akan dikembangkan, sehingga bisa diketahui apa pentingnya dan kegunaan mengembangkan bahan ajar tersebut (2) tahapan penelitiannya terperinci, sehingga mudah

\footnotetext{
${ }^{7}$ Borg \& Gall, Education Research, An Introduction (New York and London. Longman Inc.1979), hlm.626
} 
diikuti alurnya dan memudahkan peneliti untuk melakukan penelitian (3) adanya 3 tahapan revisi sehingga kualitas dalam membuat produk sangat bagus.

Menurut Borg \& Gall, ${ }^{8}$ pendekatan Reasearch and Development (R\&D) dalam pendidikan terdiri dari sepuluh langkah, yaitu :

1. Research and information collecting (melakukan penelitian dan pengumpulan informasi)

2. Planning (melakukan perencanaan)

3. Develop preliminary form of product (mengembangkan bentuk awal produk)

4. Preliminary field testing (melakukan uji lapangan awal)

5. Main product revision (melakukan revisi produk utama)

6. Main field testing (merlakukan uji lapangan untuk produk utama)

7. Operational product revision (melakukan revisi produk operasional)

8. Operational field testing (melakukan uji lapangan terhadap produk final)

9. Final product revision (melakukan revisi produk final)

10. Dissemination and implementation (diseminasi dan implementasi)

\section{Prosedur Penelitian dan Pengembangan}

Tahap pengembangan bahan ajar tematik berbasis islam \& kearifan lokal ini disederhanakan menjadi 9 tahap meliputi tahap studi pendahuluan, perencanaan, pengembangan draf awal produk, uji ahli, revisi hasil uji ahli, uji coba terbatas, penyempurnaan uji coba terbatas, uji coba lapangan, dan penyempurnaan akhir.

${ }^{8}$ Borg \& Gall, hlm.626. 


\section{Studi Pendahuluan}

Studi pendahuluan merupakan tahap pertama yang harus dilakukan peneliti dalam penelitian pengembangan. Studi pendahuluan penting dilakukan untuk mengetahui teori dan kondisi lapangan yang akan disajikan tempat uji coba produk yang dikembangkan

\section{Perencanaan}

Tahap selanjutnya dari model pengembangan ini adalah tahap perencanaan, adapun kegiatan yang dilakukan oleh peneliti pada tahap ini yaitu mengidentifikasi Kompetensi Inti (KI) dan Kompetensi Dasar (KD), mengembangkan indikator berbasis Islam \& Kearifan Lokal, Perumusan tujuan \& metode pembelajaran, merumuskan penilaian.

\section{Pengembangan Draf Awal Produk}

Tahap ini peneliti mengembangkan produk awal dengan melakukan penyusunan prototype bahan ajar berbasis islam \& kearifan lokal kabupaten . Kegiatan pada tahap ini yaitu pemetaan kompetensi dasar dan indikator ke dalam sub tema, mengembangkan materi bahan ajar berbasis Islam \& Kearifan Lokal, mengembangkan penilaian sesuai standar penilaian Kurikulum 2013

\section{Uji Ahli}

Uji ahli produk dilakukan sebelum digunakan dalam kegiatan pembelajaran. Uji produk dimaksud agar bahan ajar tematik yang dikembangkan layak digunakan dalam kegiatan pembelajaran dan dapat digunakan untuk mencapai tujuan pembelajaran yang telah ditetapkan . validasi produk yang dibuat akan divalidasi oleh para ahli.

\section{Uji Coba Produk Skala Terbatas}

Setelah dilakukan uji ahli, tahap selanjutnya yang dilakukan peneliti adalah simulasi melaksanakan bahan ajar berbasis kearifan lokal kabupaten Mojokerto kemudian dijadikan dasar revisi kedua. 


\section{Penyempurnaan Hasil Uji Coba Terbatas}

Berdasarkan hasil penilaian, masukan, tanggapan, dan saran dari siswa, maka perlu melakukan penyempurnaan bahan pembelajaran tematik hasil uji coba terbatas. Pada tahap ini perbaikan dilakukan dengan memperhatikan bahwa bahan ajar yang dikembangakn oleh peneliti bisa digunakan dengan baik oleh semua siswa.

\section{Uji Coba Lapangan}

Uji coba lapangan dilakukan untuk mengetahui keefektifan bahan ajar pembelajaran tematik. Uji coba lapangan ini dilakukan pada semua siswa kelas IV MIS Nurul Amal Mojokerto sebanyak 24 siswa dan siswa kelas IV MIN Seduri sebanyak 27 siswa .

\section{Penyempurnaan Produk Akhir}

Tahap terakhir dari penelitian dan pengembangan yang dilakukan peneliti yaitu penyempurnaan produk akhir. Berdasarkan ahsil penelitian dan masukan dari uji coba lapangan maka perlu dilakukan perbaikan sekali lagi. Perbaikan-perbaikan yang telah dilakukan peneliti dari masukan-masukan, penilaian, serta saran baik dari ahli maupun pengguna, maka akan diperoleh produk akhir berupa bahan ajar tematik berbasis Islam \& Kearifan Lokal Kabupaten Mojokerto yang memiliki kelayakan dari aspek angket guru dan siswa dan keefektifan selama menggunakan produk tersebut.

\section{Hasil}

Penelitian pengembangan ini akan menghasilkan produk berupa bahan ajar tematik pada sub tema "Keunikan Daerah Tempat Tinggalku". Uji coba dilakukan pada subyek uji coba yaitu tanggapan ahli isi/materi, ahli desain dan ahli bahasa, tanggapan guru, uji coba kelompok kecil dan uji coba lapangan. Data hasil uji coba akan dipaparkan sebagai berikut. 
Rekapitulasi Hasil Uji Validasi Ahli

\begin{tabular}{lll}
\hline No. & Subyek & $\begin{array}{l}\text { Bahan } \\
\text { Tematik (\%) }\end{array}$ \\
\hline 1 & Ahli isi/materi & $81,81 \%$ \\
2 & Ahli desain & $96,42 \%$ \\
3 & Ahli bahasa & $89,28 \%$ \\
& Total perolehan & $267,51 \%$ \\
& Rata-rata & $89,17 \%$ \\
\hline
\end{tabular}

Dari tabel di atas dapat dilihat hasil rekapitulasi tingkat kelayakan produk mencapai $89,17 \%$. Rata-rata tersebut menunjukkan bahwa "Produk ini berada pada kriteria sangat valid dan dapat digunakan dalam kegiatan pembelajaran".Kevalidan tersebut dilihat dengan kesesuaian bahan ajar tematik berdasarkan kriteria pada spek isi/materi, desain, dan aspek bahasa.

\section{Data Uji Coba Kelompok Kecil}

Uji coba kelompok kecil dilakukan di MIN Seduri pada hari/tanggal kamis, 20 Oktober 2017 dan Uji coba kelompok kecil dilakukan di MIS Nurul Amal pada hari/tanggal Jumat, 21 Oktober 2017 . Subyek uji coba sebanyak 10 orang siswa kelas IV MIN Seduri \& 10 orang siswa kelas IV MIS Nurul Amal. Kesapuluh siswa tersebut terdiri dari 4 anak berkemampuan baik, 3 anak berkemampuan sedang, dan 3 anak berkemampuan rendah.Tujuan uji coba kelompok kecil adalah untuk mengetahui kemenarikan bahan ajar.

Proses uji coba berlangsung selama 60 menit di akhir setelah semua kegiatan pembelajaran 1 sampai 6 berakhir. Hal ini dimaksudkan agar penilaian yang diberikan siswa betul-betul sesuai dengan apa yang mereka alami, mereka merasakan selama menggunakan bahan ajar pada saat kegiatan pembelajaran. Dan 
peneliti tetap mendampingi siswa agar dapat memberikan penjelasan bila mana siswa mengalami kesulitan.Hasil uji coba di MIN Seduri dapat disajikan pada perolehan rata-rata dari uji coba kelompok kecil sebesar 94,75\% dan 91,5\%. Perolehan ratarata dari kedua sekolah yaitu MIN Seduri dan MIS Nurul Amal sebesar 93,12\% setelah dikonversi tingkat kemenarikan yang ditentukan pada bab III, hasil uji coba kelompok kecil bahan ajar masuk dalam kategori sangat menarik dan dapat digunakan dalam kegiatan pembelajaran..

Rekapitulasi penyajian dan analisis data aktivitas dan hasil belajar siswa di MIN Seduri dapat dilihat pada tabel berikut ini.

Rekapitulasi Keefektifan Produk di MIN Seduri

\begin{tabular}{|c|c|c|c|}
\hline No. & Sumber data & Skor perolehan & $\begin{array}{l}\text { Kriteria } \\
\text { Penilaian }\end{array}$ \\
\hline 1 & $\begin{array}{l}\text { Aktivitas belajar } \\
\text { siswa }\end{array}$ & $60,34 \%$ & Aktif \\
\hline \multirow[t]{2}{*}{2} & $\begin{array}{l}\text { Hasil belajar } \\
\text { siswa }\end{array}$ & $100 \%$ & Tuntas \\
\hline & Rata-rata Skor & $80,17 \%$ & Sangat efektif \\
\hline
\end{tabular}

Dari tabel di atas menunjukkan bahwa rata-rata perolehan aktivitas belajar siswa dan hasil belajar siswa mencapai skor 60,34\% dan masuk dalam kriteria Aktif (60,34\% diperoleh dari rata-rata aktivitas siswa aspek sikap dijumlahkan dengan rata-rata aktivitas siswa aspek ketrampilan dibagi dua). Sedangkan indikator hasil belajar siswa menunjukkan hasil perolehan sebesar $100 \%$ siswa mencapai skor $\geq 70$ dari 100 sebagai mana kriteria efektivitas kelayakan produk.

Berdasarkan analisis pada dua indikator keefektifan produk di atas, dapat dikatakan bahwa "Bahan ajar tematik efektif digunakan dalam pembelajaran di MIN Seduri Kabupaten Mojokerto" 
Rekapitulasi penyajian dan analisis data aktivitas dan hasil belajar siswa di MIS Nurul Amal dapat dilihat pada tabel berikut ini.

Rekapitulasi Keefektifan Produk di MIS Nurul Amal

\begin{tabular}{|c|c|c|c|c|}
\hline No. & Sumber & ata & Skor perolehan & $\begin{array}{l}\text { Kriteria } \\
\text { Penilaian }\end{array}$ \\
\hline 1 & $\begin{array}{l}\text { Aktivitas } \\
\text { siswa }\end{array}$ & belajar & $51,70 \%$ & Cukup aktif \\
\hline \multirow[t]{2}{*}{2} & $\begin{array}{l}\text { Hasil } \\
\text { siswa }\end{array}$ & belajar & $100 \%$ & Tuntas \\
\hline & Rata-rata & kor & $75,85 \%$ & Sangat efektif \\
\hline
\end{tabular}

Dari tabel di atas menunjukkan bahwa rata-rata perolehan aktivitas belajar siswa dan hasil belajar siswa mencapai skor 51,70\% dan masuk dalam kriteria cukup aktif (51,70\% diperoleh dari rata-rata aktivitas siswa aspek sikap dijumlahkan dengan ratarata aktivitas siswa aspek ketrampilan dibagi dua). Sedangkan indikator hasil belajar siswa menunjukkan hasil perolehan sebesar $100 \%$ siswa mencapai skor $\geq 70$ dari 100 sebagai mana kriteria efektivitas kelayakan produk.

Berdasarkan analisis pada dua indikator keefektifan produk di atas, dapat dikatakan bahwa "Bahan ajar tematik efektif digunakan dalam pembelajaran di MIS Nurul Amal Kabupaten Mojokerto"

ditentukan.

Rekapitulasi data keterterapan produk bahan ajar diperoleh dari uji coba lapangan menggunakan angket tanggapan guru dan siswa disajikan pada tabel 4.24 berikut. 
Tabel Rekapitulasi angket keterterapan produk

\begin{tabular}{llll}
\hline No. & Subyek uji coba & Persentase & Kriteria Penilaian \\
\hline 1 & Guru & $84,17 \%$ & Sangat baik \\
2 & Siswa & $88 \%$ & Sangat baik \\
& Rata-rata skor & $86,08 \%$ & \\
\hline
\end{tabular}

Berdasarkan data pada tabel di atas menunjukkan angket tanggapan guru memperoleh skor $84,17 \%$ dan ratarata akhir angket tanggapan siswa sebesar $88 \%$. Sedangkan rata-rata angket anggapan guru dan siswa sebesar 86,08\%. Setelah dikonversikan persentase tersebut masuk dalam kategori sangat baik. Berdasarkan analisis tabel keterterapan produk diatas, dapat dikatakan bahwa

"Produk bahan ajar tematik telah memenuhi unsur keterterapan untuk dijadikan bahan pembelajaran".

\section{Simpulan}

Berdasarkan hasil penelitian dan pengembangan dapat disimpulkan, bahan ajar tematik mampu memecahkan permasalahan bahan ajar yang digunakan oleh guru. Produk yang telah dikembangkan telah memenuhi komponen kelayakan seperti kevalidan, kefeektifan, keterterapan, dan kemenarikan sebagai bahan ajar yang baik, sehingga bahan ajar ni dapat mengisi kekurangan dan menambah keragaman sumber belajar tematik khususnya di kelas IV MIN Seduri dan MIS Nurul Amal untuk digunakan guru dan siswa.

Bahan ajar tematik yang dikembangkan telah melalui uji kelayakan sebagai sumber yang baik dan secara spesifik dikembangkan sesuai dengan budaya, lingkungan siswa dan kurikulum. Bahan ajar ini telah teruji kevalidannya oleh ahli isi/materi, ahli desain dan ahli bahasa dengan kriteria sangat valid.b Berdasarkan penilaian siswa, bahan ajar ini sangat menarik untuk digunakan dalam pembelajaran. Bahan ajar tematik ini memiliki keefektifan yang tinggi berdasarkan aktivitas siswa selama 
proses pembelajaran dan ketercapaian tujuan pembelajaran yang diukur secara kalsikal melalui ketuntasan hasil belajar siswa. Keterterapan bahan ajar ini sangat baik berdasarkan penilaian siswa dan guru setelah menggunakan bahan ajar dalam proses pembelajaran.

Bahan ajar tematik ini memiliki kelebihan dan kekurangan. Kelebihan terdapat dalam bahan ajar tematik ini antara laian : (1) didesain dengan karakteristik siswa sesuai dengan budaya di Kabupaten Mojokerto dan dekat dengan lingkungan siswa berada, (2) peran siswa terlihat lebih banyak dalam kegiatan pembelajaran karena siswa mengalami langsung dalam kegiatan pembelajaran dan guru benar-benar sebagai vasilitator dalam kegiatan pembelajaran, (3) dilengkapi dnegan gambar-gambar menarik yang realistik, sehingga kegiatan pembelajaran lebih kontekstual yang membuat siswa memiliki daya tarik yang tinggi dalam menggunakan bahan ajar tematik ini, (4) kegiatan pembelajaran bukan hanya dilakukan di dalam kelas tetapi dapat dilakukan di luar kelas, sehingga dapat mengalami langsung baik melalui kegiatan mandiri melalui tugas rumah maupun kegiatan bersama guru saat pembelajaran berlangsung, (5) bahan ajar yang dikembangkan dengan mengintegrasikan nilai-nilai Islam melalui pembiasaan di dalam pembelajaran.

Kekurangan yang terdapat di dalam bahan ajar tematik ini hanya berfokus pada satu sub tema. Kekurangan tersebut disebabkan oleh keterbatasan waktu dalam peneliti mengembangkan bahan ajar tematik ini, selain itu bahan ajar tematik ini hanya bisa digunakan di lingkungan Kabupaten Mojokerto dan perlu penyesuaian apabila digunakan di daerah lain. 


\section{Referensi}

Abdul Majid. Pembelajaran Tematik Terpadu. Bandung : PT. Remaja Rosdakarya, 2014.

Achmadi. Islam Sebagai Paradigma Ilmu Pendidikan. Yogyakarta: Aditya Media, 1992.

Akbar \& Sriwijaya. Pengembangan Kurikulum dan Pembelajaran Ilmu Pengetahuan Sosial. Yogyakarta : Cipta Media, 2011.

Alexon \& N.S.Sukmadinata. "Pengembangan Model Pembelajaran Terpadu Berbasis Budaya untuk meningkatkan Apresiasi Siswa terbadap Budaya Lokal " Jurnal Cakrawala Pendidikan (Juni 2010) th. XXXIX. No. 2

Amin, M. Panduan Pengembangan Bahan Ajar IPA. Jakarta : Depdiknas, 2006.

Amin, Mohammad, Widodo, Wahono, Pratiwi, Panduan Pengembangan Baban Ajar IPA, Direktorat Jenderal Pendidikan Dasar dan Menengah : DEPDIKNAS, 2006.

Sirojuddin, Akhmad. 'Pengembangan Bahan Ajar Mind Mapping Berbasis ICT'. Nidhomul Haq : Jurnal Manajemen Pendidikan Islam 1, no. 1 (2016): 13-24. https://doi.org/10.31538/ndh.v1i1.4.

Borg \& Gall. Education Research, An Introduction : Third Edition. New York and London. Longman Inc.1979.

Kemendikbud. Bahan Ajar Pengelolaan Pembelajaran Tematik Terpadu. Jakarta : Kemendikbud, 2013c.

Kuntowijoyo. Paradigma Islam:interprestasi untuk aksi. Jakarta: PT.Mizan, 2008.

Mujib, Abdul ;Abdul, Jusuf Mudzakir. Ilmu Pendidikan Islam. Jakarta : Kencana Prenada Media, 2006.

Mulyasa, Pengembangan dan Implementasi Kurikulum 2013 (Bandung : PT. Remaja Rosdakarya, 2014.

Mungmachon, R., Knowledge and Local Wisdom: Community Treasure. International Journal of Humanities and Social Sciences. Vol.2 No.13 (july 2012). 
Ma`arif, Muhammad Anas. 'Pendidikan Islam Dan Tantangan Modernitas'. Nidhomul Haq: Jurnal Manajemen Pendidikan Islam 1, no. 2 (26 March 2016): 47-58.

Nadlir. Urgensi Pembelajaran Berbasis Kearifan Lokal, Jurnal Pendidikan Agama Islam. Volume 2, Nomor 2, November, 2014.

Nizar, Samsul. Filsafat Pendidikan Islam, Pendekatan Historis, Teoritis, dan Praktis. Jakarta : Ciputat Press, 2002.

Panen, P \&Purwant. Penulisan Bahan Ajar. Jakarta : Pusat antar Universitas untuk

Pusat Penelitian dan Pengembangan Kebudayaan. Kearifan Lokal ditengah Modernisasai. Jakarta : Pusat Penelitian dan Pengembangan Kebudayaan Badan Pengembangan Sumber Daya Kebudayaan dan Pariwisata Kementerian Kebudayaan dan Pariwisata Republik Indonesia, 2011.

Reigeluth, C.M.. Instructional Design Theories and Models : an Overview of their current Status. New Jersey : Lawrence Erlbaum associates publisher, 1992.

Rosyidia, Anindia Desy, Pengembangan Buku Ajar Tematik Terpadu Berbasis Kearifan Lokal, Muallimuna, 2015 ISSN : 24769703, Volume 1, Nomor 1.

Rusman. Model-model Pembelajaran. Bandung : PT. Raja Grafindo Persada, 2010.

Wagiran. Pengembangan Karakter Berbasis Kearifan Lokal Hamemayu Hayuning Bawana, Jurnal Pendidikan Karakter, Th.2 No.3 Oktober 2012.

Wardahlia Kurniawati, Aisyah. Pendidikan Nilai Berbasis Islam (Proses Penanaman Budi Pekerti dalam Bingkai Pendidikan Agama Islam). Malang : UIN Malang Skripsi, 2009.

Yunanto, S.J. Sumber Belajar Anak Cerdas . Jakarta : PT. Grafindo, 2004.

http://irmanoviantiade.blogspot.co.id/2014/05/jenis-jenisbahan-ajar-dan-pemilihan.html http://nurhidayatibj.blogspot.co.id/2013/05/bahanajar 8069.html 